Introductory article

\title{
The Russian language maintenance and language contacts
}

\author{
Anastassia ZABRODSKAJA ${ }^{\mathbf{1}}$ and Olga IVANOVA ${ }^{\mathbf{2}}$ \\ ${ }^{1}$ Tallinn University \\ Tallinn, Estonia \\ ${ }^{2}$ University of Salamanca \\ Salamanca, Spain
}

\begin{abstract}
In our introductory article, we outline the main sociolinguistic features of Russian as a heritage language of post-Soviet immigrants in European settings and beyond. We offer a general overview of the evolution of Russian as a global language, with a particular focus on its geodemographics and economic and social value as a lingua franca. Based on this, we analyse the main principles defining the maintenance of Russian as a language of migration and as a heritage language in different countries, and emphasise the most important questions that still need to be addressed in this field of research. The main objective of this special issue is to combine the most recent research on the vitality of different languages of post-Soviet republics in new political milieu, with a particular focus on European and Asian countries, but there are other objectives as well. We propose to explore the factors that have either favoured or hindered the maintenance and transmission of languages of postSoviet immigrants and repatriates, and how these sociolinguistic processes become evident in language vitality on both private and public levels. Our special issue primarily addresses the questions of family language policy, new language contacts and their management, and linguistic landscape in heritage speakers, diasporas and their new settings in Europe, Asia and the US.
\end{abstract}

Keywords: post-Soviet migrants, heritage language, multilingualism, language policy, language contacts

\section{For citation:}

Zabrodskaja, Anastassia \& Olga Ivanova. 2021. The Russian language maintenance and language contacts. Russian Journal of Linguistics 25 (4). 828-854. https://doi.org/10.22363/2687-0088-2021-25-4-828-854 


\title{
Сохранение русского языка и языковые контакты
}

\author{
${ }^{1}$ Таллинский университет \\ Таллин, Эстония \\ ${ }^{2}$ Университет Саламанки \\ Саламанка, Испания
}

Анастасия ЗАБРОДСКАЯ ${ }^{1}$ и Ольга ИВАНОВА ${ }^{2}$

\begin{abstract}
Аннотация
В данной статье мы обрисовываем основные социолингвистические особенности русского языка как эритажного в среде постсоветских иммигрантов в Европе и за ее пределами. Мы предлагаем общий обзор эволюции русского как глобального языка, с особым акцентом на его геодемографию и экономическую и социальную ценность как лингва франка. Исходя из этого мы анализируем основные принципы, определяющие сохранение русского языка как языка миграции и как эритажного в разных странах и выделяем наиболее важные вопросы, которые еще предстоит решить в этой области исследований. Основная цель этого специального выпуска - объединить самые последние исследования жизнеспособности различных языков постсоветских республик в новой политической среде, обращая особое внимание на страны Европы и Азии, хотя мы также ставим и другие цели. Мы предлагаем изучить факторы, которые способствуют или препятствуют сохранению и передаче языков постсоветских иммигрантов и репатриантов, а также то, как эти социолингвистические процессы проявляются в жизнеспособности языка как на частном, так и на государственном уровнях. В нашем специальном выпуске в первую очередь рассматриваются вопросы семейной языковой политики, новых языковых контактов и управления ими, а также языкового ландшафта среди эритажных носителей языка, диаспор и их нового окружения в Европе, Азии и США.
\end{abstract}

Ключевые слова: постсоветские мигранты, эритажный язык, мультилингвизм, языковая политика, языковые контакты

\section{Для цитирования:}

Zabrodskaja A., Ivanova O. The Russian language maintenance and language contacts. Russian Journal of Linguistics. 2021. Vol. 25. № 4. P. 828-854. https://doi.org/10.22363/2687-00882021-25-4-828-854

\section{Introduction}

The sociolinguistic situation of languages of the post-Soviet states, both as national and heritage languages, has been dynamic and highly heterogeneous in the past three decades. The situation of the Russian language is, probably, one of the most complex and challenging in terms of its sociolinguistic and psycholinguistic framework. Russian is a supranational language, with more than half of its speakers living outside the Russian Federation. It is difficult to estimate how many speakers of the Russian language actually live outside Russia, and the first obstacle to determining this is the variety of terms that are used in referring to them. Based on official documents from the Russian government, Pieper (2020) mentions at least six common terms (ethnic Russians, Russian-speakers, cultural Russians, compatriots, countrymen abroad and fellow tribesmen), which reflect, in the author's opinion, uncertainty about whom to include in this group. Indeed, 
historically Russian was not considered a language of an ethnic nation-state, but rather a "transnational connector" with functional and affective symbolism during the Soviet era (Ryazanova-Clarke 2017). As a result, current estimates show that, in addition to 146.1 million speakers living in Russia, there are approximately 32 million native speakers of Russian in the surrounding area and between 130 and 160 million speakers who use Russian as a second language all around the world (Ustinova 2016). These data place the Russian language among the ten leading world languages (Aref'ev 2014).

At present, Russian performs different functions in different sociolinguistic settings, and it is necessary to revisit social correlates of its maintenance or loss in immigrant environments. In addition to its status as a native and second language internationally, the Russian language also gained new roles outside Russia, and post-Soviet migration played a very important role in this. Extended knowledge of Russian among post-Soviet citizens not only allowed it to maintain its status as a lingua franca and a language of international communication, but also to strengthen its position in new, previously unknown ways. Among these, two new functions have received little attention: the commodification of Russian and its consolidation as a heritage language worldwide.

Concerning the first function, recent research reveals that Russian has gained a commodity which "relies on the promise of mutual understanding and the elimination of barriers for successful communication" (Muth 2017a: 405). Consequently, in many European countries (and non-European ones) Russian began to occupy an important market position, which assures its role not only as a language of international and interethnic communication, but also as a language with economic value (see Muth 2017b, Suryanarayan 2017, Viimaranta et al. 2017 etc.). Within the original theory of commodification, according to Duchêne and Heller (2012), languages are defined in terms of their ability to generate economic profit. In this respect, the situation of Russian in the worldwide arena may be described in Pavlenko's (2015: 387) definition of languages as commodities, i.e. their role as market values: " $(\mathrm{t})$ he corollary of this trend is a shift from the discourses of 'pride' that tie languages to identities, territories, and nation-states to the discourses of 'profit' that frame languages in economic terms as commodities useful for production of resources."

However, it is the second new function of Russian, which deserves deeper attention because of its dynamics and direct effect on the understanding of the sociolinguistic value of the language. The linguistic destiny of Russian is unique, since it is a widespread language with multiple possible functions: native language or one of the first acquired languages, one of the home languages or a heritage language, a language of cultural heritage, a lingua franca, a minority language or a language of a minority group, a language of commodification, a language of a former occupier, a foreign language, a language of power, a tool of soft power, a language of (linguistic, political, geopolitical, etc.) tensions, a language for debates, etc. Indeed, this peculiar sociolinguistic situation of Russian has led to an extensive 
area of research dealing with its scope as a language of diaspora and a heritage language in immigrant populations. One of the most challenging issues relates to the understanding of social and psycholinguistic aspects that drive its maintenance in immigrant families and among groups of ex-pats from different post-Soviet states. Interestingly, these countries themselves are important subjects of sociolinguistic analysis, since different approaches to national language policies have given rise to highly heterogeneous status levels of Russian and its presence in linguistic milieux.

Russophone communities - let us use this term instead of 'diaspora,' following suggestions of caution from Ryazanova-Clarke (2014), who defines 'diaspora' as less accurate for referring to all possible Russian-speakers outside Russia because it implies strong links to the homeland - are numerous and variable. Their sociolinguistic positions may be stronger or weaker, and the statuses of contact languages and cultures have a great deal to do with the vitality of Russian and its intergenerational maintenance or shift. One should also not ignore the role of attitudes and the divergence between attitudes and language competence in immigrant communities (cf. Lasagabaster 2008).

At the same time, these new sociolinguistic realities have always gone hand in hand with Russian in a new jacket (Pavlenko 2017). In summary, understanding sometimes incomparable situations may be highly enriching for the sociolinguistic description of the Russian language. According to Cheskin \& Kachuyevski (2019: 4), "it is important to examine why different, generalised trends in language use, self-identification and group identification are occurring across the post-Soviet space".

The sociolinguistic situation of Russian as a heritage language still leaves many questions unanswered and it is the purpose of this special issue to contribute to a deeper understanding of some of them. It offers new comparative studies on Russian as a heritage language transmission and maintenance in countries with (to some extent) the historical presence of Russian (e.g. Estonia, Germany, Israel, Sweden and the USA) but also in less studied milieux with very recent histories of Russian as a heritage language (e.g. Spain, Cyprus, India, South Korea and Japan). Furthermore, this special issue aims to reflect different current aspects of Russian as a heritage language: it gathers works on different communicative and functional roles of Russian as a heritage language, on family language policy related to Russian as a heritage language in different countries, on longitudinal changes in its sociolinguistic status, and on the structural changes that speakers produce in Russian as a heritage language. Thus, the contributors discuss different sociolinguistic variables which drive first-generation migrants to transmit or not to transmit their native languages to second-generation speakers; the peculiarities of identity construction in different generations of migrants; phenomena which characterise language choice and heritage language systems in successive generations; and the visibility of migrant languages in such settings as a linguistic landscape. 


\section{The Russian language in post-Soviet immigrant communities}

The Russian language has spread all around the world. Apart from the Russian Federation and the fourteen national states resulting from the disintegration of the Soviet Union, there are numerous countries where a significant number of Russophones have settled. In addition to the traditional destinations of Israel, Germany and the United States (Ben-Rafael et al. 2006), Russophone immigrant communities have recently become particularly large in Western Europe, the Near East and Asia. As stated above, most of them are internally linked by the Russian language rather than by specific ethnic or national adscription. Laitin (1998) even defined the Russian language as the marker of group identity among Russophone communities abroad, though some caution is called for in terms of different identities and attitude backgrounds among post-Soviet immigrants. Cheskin \& Kachuyevski (2019) insist that Russophone identities are complex and vary among communities the Russian language is spoken in.

As a result, different definitions are currently applied to Russian as a means of communication, identity and commodification outside Russia. For post-Soviet states, it is common to define Russian as a lingua franca, a language of inter-ethnic communication, an official language, a minority language or a foreign language in the newly generated sociolinguistic landscapes. Importantly, as Pavlenko (2006) suggests, the role of Russian as a lingua franca is extremely variable within the national policies of de-Russification, and there has been extensive research on shifting language negotiation in the fourteen post-Soviet national states (e.g. Pavlenko 2008). Major findings set the Baltic States apart, with their deep and pervasive pro-national language policies (Brubaker 2014), and the Caucasian countries, which excluded Russian from legislation (Hogan-Brun \& Melnyk 2012), from the Central Asian countries, with Russian-favouring language policies that recognise Russian as either an official or inter-ethnic communication language (Aminov et al. 2010). Such East European states as Belarus, Ukraine and Moldova form a particular group of countries with shifting dynamics in language management. Whilst Belarus adopted Russian as its second state language, which is currently used as a de facto main language of the country (Pavlenko 2013), and Moldova is polarised between the national Moldovan and the prestigious Russian (Prina 2012), Ukraine has gone through different stages of language regulation involving extreme degrees of politicisation of the language question (Csernicskó 2017, Smaglo 2020).

Considering countries beyond the post-Soviet area, the Russian language is mainly conceived of as a common and shared trait among immigrants. In postSoviet immigrant communities, Russian frequently serves as the lingua franca and the language of interethnic communication, independently of the ethnic or national groups of the speakers (cf. Ryazantsev 2015). Importantly, not all post-Soviet immigrants are Russophones. Malyutina (2020) stresses the importance of discerning among those post-Soviet immigrants who use Russian and those who want nothing to do with it, in order to avoid any superficial or oversimplified 
approach to diaspora. This seems to be a very relevant observation, considering that historically there has been a general tendency to label as 'Russian' any immigrant from the former Soviet Union (see, for example, Andrews 1998 on such a historical perspective).

Despite these differences, it is the Russian language that has received a lot of explicit support outside Russia. The Russian Federation launched the "compatriots project", aimed at engaging with Russian nationals living abroad, specifically encouraging connections with the homeland and using such connections to promote Russia and Russian in the West (Byford 2012). The effects of this project extend to many post-Soviet immigrants. As Suslov (2017: 10) puts it, the "Russian diaspora is not a diaspora in the strict sense, nor is it 'Russian"': compatriot groups worldwide not only include Russian citizens living abroad, but also immigrants from the Soviet Union, Russian-speaking former Soviet citizens, Russian nationals and former Soviet nationals in general. These immigrant communities are united by a common history and shared memories, and Russian plays a key role in these ties (Elias \& Shorer-Zeltser 2006). A shared language and culture, as Mustajoki, Protassova \& Yelenevskaya (2020a) state clearly, can have much more power in consolidating a diaspora successfully than any principle of ideological or political loyalty. Thus, generally speaking, the sense of belonging to a Russophone diaspora is not tied to political allegiances (Golova 2020).

In some host countries, the role of the Russian language as the means of communication of the diaspora has already achieved considerable success. In Israel, for example, Russian is systematically used in a very extensive network of print and electronic media (Elias 2011). Based on narratives from immigrants in Israel, Yelenevskaya \& Fialkova (2003) showed that there is deep language awareness among Russian-speakers in Israel about its value and functional possibilities. As a result, Russian has been used even in the most formal situations, e.g. in business and high-tech industry. A similar situation exists in Germany and the United States, with extensive Russophone communities located in both of them. In Germany, there are approximately six million speakers of the Russian language, most of whom consider Russian their identity marker (Hamann et al. 2020). As a result, the Russian language is maintained and used in multiple contexts, from education (mainly kindergartens and primary schools) to commercial infrastructure, massmedia and social media, as well as medical institutions (Bergmann 2015). In the United States, with more than three million speakers of Russian as of 2010 (Aref'ev 2014), Russian acts as a language of immigrants' social context (Hubenthal 2004), which is positively viewed, learnt and used by many heritage speakers (Kagan 2010). The public presence of Russian in the USA is very extensive, including not only in the press, but also in legal and medical services, educational settings, commercial infrastructure and, especially, academia (Kagan \& Dillon 2010). In all the three mentioned countries, there is a generally positive attitude among Russianspeaking groups towards Russian as a heritage language, ensuring maintenance and transmission from generation to generation (cf. Moin et al. 2011 for Israel and 
Germany, and Kagan 2010 for USA). However, the sociolinguistic status and functionality of Russian in other countries with major Russophone communities does not necessarily follow the same pattern. In some of them, the reason may be greater dispersion of Russian-speakers throughout the country, with less cohesive (and fewer) community connections. An example is the Russian-speaking immigrants in Great Britain, which is a highly fragmented community with strong social and cultural differences and diverse community practices (Byford 2012). As Byford (2012) reports, there is a Russian-based network of establishments within a Russian-speaking migrant marketplace, including material (products, labour, services, etc.) and symbolic (information, favours, contacts, etc.) forms of exchange, but it is clearly aimed at a dispersed and somewhat undefined target group, which is mainly tied through informal social networking.

In other countries, the presence of Russophones is very recent and the diaspora is not clearly organised. The most salient examples may be the Russian-speaking communities in Southern Europe, where Russian is one of the many minority immigrant languages, with challenging, dynamic and variable sociolinguistic situations. In Italy, for example, the Russophone community is characterised by individualism and atomism, mainly because of its relatively small size and high dispersion throughout the country (Perotto 2014). In her sociolinguistic study, Perotto (ibid) found that most members of this community were not very concerned with the maintenance of contact with other Russophones or with the preservation of the Russian language.

In summary, the sociolinguistic situation of the Russian language in postSoviet immigrant communities is highly variable and unstable. As Yelenevskaya \& Protassova (2015) point out, present-day diasporas are defined by the transnationality of their social, cultural and economic activities. This is one of the factors that explain the sociolinguistic variation in Russophone diasporas, but definitely more research is needed on more specific (national-specific and community-specific) factors that explain (and predict) the functional and symbolic value of Russian as a language of immigrants. In this respect, one of the first steps needed is to look at factors that either favour or hinder the maintenance of Russian as a heritage language in different communities around the world.

\section{Russian as a heritage language}

The status of the Russian language as a heritage language varies greatly among communities. In some of them, Russian is a transgenerational full-fledged heritage language with a long sociolinguistic history. Such deep-rooted diasporas are composed of both Russian-speaking émigrés' descendants and newcomers (Mustajoki et al. 2020a). However, not all members of such diasporas maintain the Russian language and culture over time (Smyth \& Opitz 2013). In fact, even in countries with important Russophone communities, such as Germany, many members of the second generation of immigrants assimilate linguistically (Golova 2020) and it is clear that there are multiple factors conditioning the maintenance of 
Russian as a heritage language universally. It should be added that Russian does not remain stable and that changes and variations are inevitable (see Ryazanova-Clarke 2014 for some background reading).

Sociolinguistic and psycholinguistic research on heritage languages shows that such factors may be classified as external or internal, and that they do not act separately in driving heritage language maintenance. There are multiple factors involved in heritage language maintenance or language shift over time, and studies show the role of factors conditioned by the receiving society and factors coming from heritage language speakers themselves (Schalley \& Eisenchlas 2020). Indeed, the social value of a heritage language with minority status is determined by the roles it plays in the host society. Hornberger (2005) has suggested that all global characteristics of the host community play a role in heritage language maintenance, including heritage language sociolinguistic status, heritage language speakers' attitudes and heritage language presence in different public domains, such as education and the labour market. The functional potential of a heritage language outside of the home is also important. The frequency of use and the possible communicative roles of a heritage language both within and outside of family contexts are highly influential in respect to its vitality (Banfi 2018). Among other factors, research highlights the role of the prestige of a heritage language and the cultural background it conveys (Romanowski 2021), the opportunities for a heritage language to be used in situations with socioeconomic opportunities, e.g. in education, the labour market, media, healthcare systems or any other public service (Aalberse et al. 2019), the degree of self-identification with heritage language culture and positive attitudes to its symbolic and functional values (Ivanova 2019), and the amount of exposure to a heritage language and the degree of reduction of such input at home (Montrul 2016). In summary, Aalberse, Backus \& Muysken's (2019: 49) statement seems particularly true: "Perhaps the main conclusion of many years of research on maintenance and shift is that there are so many factors that play a role, and they play it so differently in concrete cases, that it has proven impossible to construct a single widely accepted theory that accounts for maintenance and shift and that predicts what will happen in any given bilingual setting." Thus, social factors are systematically complemented with a set of individual characteristics of the speakers: their age, gender, marital status, language knowledge, reasons for migration, length of residence in the host country, contact group, etc. (Nesteruk 2010).

Concerning Russian as a heritage language, several observations may be made. There are some important aspects conditioning the maintenance of Russian as a heritage language in different Russophone communities. Among the most influential factors are the contact language and its social prestige, educational opportunities, socioeconomic advantages, and speakers' attitudes to the political and social associations of the Russian language as the national language of Russia. Mustajoki, Protassova \& Yelenevskaya (2020b: 5) summarise this very clearly: "Non-ideological support of the Russian language outside the nation is a sensitive 
issue that does not only require goodwill but calls for expert knowledge of local language, education policies and the economic situation that can either create incentives for Russian-language maintenance or make it irrelevant for diasporans' socioeconomic upward mobility."

In many countries, Russophone cultural institutions contribute to the maintenance of Russian as a heritage language through Sunday schools, heritage language courses or even (though less frequently) regular education. However, families seem to play the key role in the strength of Russian as a heritage language and, in this respect, it is essential to understand how family language policies are created in different Russophone communities globally.

In her description of the family language policy in Russian-speaking families in the U.S., Nesteruk (2010) mentions the necessity of following Fishman's distinction between language transmission and language maintenance for understanding bilingualism in heritage speakers: she points out that language transmission (using Russian as a heritage language with children in the family) is rather more common and successful than language maintenance (use of Russian as a heritage language by succeeding generations for multiple functions). With a focus on the Russophone diaspora in the USA, Laleko (2013) stresses that third - and fourth-generation immigrants, including post-Soviet citizens, usually display less intense emotional concern with the maintenance of Russian as a heritage language. Her conclusion in this respect is not very positive regarding the fate of Russian as a heritage language in the USA: " $<\ldots>$ assuming that language attitudes in the home serve as a predictor of continued inter-generational language maintenance in immigrant families, we may hypothesize that desire for maintaining and actively using the heritage language beyond the home and family domain may not be among the highest priorities for the American-born generation of heritage Russian speakers" (Laleko 2013: 391).

By contrast, the Finnish sociolinguistic situation shows that most family language policies favour Russian heritage language maintenance. Protassova (2008) has reported that most Russian-speaking families choose schools teaching in both Finnish and Russian or teaching Russian as the heritage language, though these results show a significant social correlation: families with low socioeconomic status are less prone to exposing their children to Russian as a heritage language. Similarly, Schwartz (2008) has shown that Russian-Jewish immigrants in Israel are highly involved in transmitting Russian as a heritage language to their children and, importantly, complain when educational and social conditions do not assure balanced exposure to Russian for their offspring. Sociolinguistic situations in regard to Russian thus vary greatly among countries, and historical issues (e.g. Russian language presence or social openness to the languages of migrants) may explain a great deal about this variation in addition to social and individual factors in the maintenance of Russian as a heritage language. Language ideologies and the management and practice of Russian as a heritage language - the three pillars of the family language policy according to Spolsky's classical model (2004) - are 
country-dependent and form a sort of kaleidoscope of shifting and fluctuating contexts favouring or hindering the preservation of Russian as a heritage language.

Finally, there is the effect of the status of Russian as a heritage language and the consequent family language policies on Russian's internal evolution and change. Limited exposure to the heritage language may have an important effect on heritage language acquisition. Reduced input is systematically argued to be the major reason for difficulties in the acquisition of certain heritage language properties, for example, and particularly for Russian as a heritage language in connection with gender (cf. Rodina et al. 2020). For Russian, referential studies have been carried out in many immigrant settings, revealing changes in the structure of Russian as a heritage language (cf. Protassova 2008 for Russian in Finland, Isurin \& Ivanova-Sullivan 2008 for Russian in the USA, and Schwarz 2008 for Russian in Israel). However, a very recent comparative study by Rodina et al. (2020) on Russian in Israel, Germany, Norway, Latvia and the UK has revealed the necessity of searching for common and contrasting traits of language change in Russian as a heritage language.

\section{Articles in this special issue}

Based on this multilateral perspective on migrants' languages and identities, this special issue addresses the following questions:

- Sociolinguistic portraits: who transmits or does not transmit their languages to the second generation? How Russian and other post-Soviet heritage languages are perceived?

- Social visibility of languages: how are these languages included in different spheres of language use (linguistic landscape)?

- Cognition and attitudes: what do post-Soviet immigrants and repatriates believe about their heritage languages and how do their beliefs influence their vitality?

- Cognition, society and language system: how do all these sociolinguistic and cognitive processes influence the transformation of the language systems of Russian and other post-Soviet languages as heritage languages in constellation with their contact languages?

Looking in detail, this issue includes case studies on language management in bilingual Russian-Estonian and Russian-Spanish families (Ivanova \& Zabrodskaja), sociolinguistic patterns of the maintenance of Russian as a heritage language in Germany (Brehmer), grammatical aspects of Russian as a heritage language in Israel (Meir et al.), grammatical changes in Russian under the influence of English among Russian-English bilinguals residing in the USA (Isurin), multilingualism and translanguaging among Russian-language speakers in Cyprus, Estonia and Sweden (Karpava et al.), the presence of Russian in the linguistic landscape of Nuremberg, Germany (Ritter) and in three Asian countries - India, Japan, and South Korea (Protassova et al.), the use of Russian, Kazakh and the spread of English in naming practices (Smagulova \& Madiyeva), and heritage language and identity 
maintenance in the Lithuanian diaspora (Ramoniene \& Ramonaitè). At the end of the current collection Branets and Verschik present a structural and extra-linguistic analysis of receptive multilingualism, providing evidence how Estonians understand Ukrainian via their knowledge of Russian. Putjata concentrates on language maintenance among multilingual teachers, presenting her research on Russian-Hebrew speakers' ideas of language related normality in educational settings. Three book reviews at the end of this issue are included with the specific aim of exemplifying how in different countries each new generation finds their own ways of using their heritage language, depending on the relationship between language and society, attitudes and perceptions. Thus, the process of the Russian language maintenance and language contacts of post-Soviet immigrants in Europe and beyond might be seen more clearly when compared with special situations involving two or more languages investigated and presented there.

\section{Conclusion}

Forced by political, economic and demographic instability, not only ethnic minorities (mostly Jews and ethnic Germans) but also ethnicities of already independent states began migrating to Central and Western European countries. Migration between newly independent states, which involved voluntary movements of repatriates, also became extremely intensive. As a natural result of migratory processes, many languages of post-Soviet immigrants became heritage languages of migrant families in the new milieux and started to consistently form part of their language settings. The linguistic outcome became multi-layered: while some postSoviet migrants formed large communities of ex-pats, which favoured heritage language maintenance, use and new-place vitality, many others integrated into their host societies and/or assimilated culturally and linguistically, leaving their heritage language behind. Our special issue shows that none of these changes happened overnight and it is difficult to discern which sociolinguistic changes are still in progress.

The expected contribution of this special issue is to analyse the patterns, which define sociolinguistic and cognitive aspects of heritage language vitality, as well as the effect of such extra-linguistic factors on the internal systems of the heritage languages. In this respect, the special issue offers proposals for the further analysis of social relations in the respective societies and of language system transformation in heritage languages. These sociolinguistic realities surrounding Russian might be shortly described by a saying in Estonian: "Heal lapsel mitu nime", that is, "A good child has many names.' In their recent edited volume, Mustajoki et al. (2020a) pose a question: "Russian as a communicative tool: Lingua franca, intermediator or something else?" and present a collection of articles trying to suggest best possible scenarios. The present special issue, while answering some old questions, leads to new ones; needless to add that some unforeseen features of Russian are discovered in a more complex situation (i.e. transfer, translanguaging, and receptive multilingualism). 
As case studies in our special issue reveal, Russian and other languages (e.g. Lithuanian) of post-Soviet immigrants in Europe and beyond might become the (cultural) heritage acquired mainly as the home language, often without conscious awareness or family language policy planning. A lot depends not only on certain uses of the language, and its educational and economic status in the larger community, but also on children as active agents who may provide their own sets of norms and expectations regarding the use of the heritage language.

\section{RU}

\section{1. Введение}

Социолингвистическая ситуация языков постсоветских государств, как национальных так и традиционных, была динамичной и весьма неоднородной в последние три десятилетия. Ситуация с русским языком, пожалуй, одна из самых сложных и богатых на вызовы с точки зрения социолингвистических и психолингвистических систем. Русский - наднациональный язык: более половины говорящих на нем проживают за пределами Российской Федерации. Трудно подсчитать, сколько носителей русского языка на самом деле проживает за пределами России, и первое препятствие для определения этого - разнообразие терминов, которые используются для их обозначения. Основываясь на официальных документах правительства России, М. Пипер (Pieper 2020 ) упоминает как минимум шесть общих терминов (этнические русские, русскоязычные, русские по культуре, соотечественники / земляки, соотечественники за рубежом и соплеменники), которые, по мнению автора, отражают неуверенность в том, кого же включать в эту группу. Действительно, исторически русский язык не считался языком этнического национального государства, а скорее «транснациональным связующим звеном» с функциональной и аффективной символикой в советское время (Ryazanova-Clarke 2017). В результате, по текущим оценкам, помимо 146,1 миллионов, проживающих в России, в прилегающих к ней районах проживает около 32 миллионов носителей русского языка, а во всем мире от 130 до 160 миллионов используют русский как второй язык (Ustinova 2016). На основе этих данных, русский язык входит в десятку ведущих мировых языков (Aref'ev 2014).

В настоящее время русский язык выполняет разнообразные функции в разных социолингвистических условиях. Необходимо пересмотреть социальные корреляты его сохранения или утраты в среде иммигрантов. Помимо статуса родного и второго языка на международном уровне, русский язык также приобрел новые функции за пределами России, и постсоветская миграция сыграла в этом очень важную роль. Знание русского языка среди постсоветских граждан не только позволило ему сохранить свой статус лингва-франка и языка международного общения, но и укрепить свои позиции новыми, ранее неизвестными функциями. Среди них двум новым функция - коммодификации русского языка и его всемирному укреплению в качестве эритажного языка - пока что было уделено мало внимания. 
Что касается первой функции, то недавнее исследование показывает, что русский язык - это коммодити, распространенный предмет потребления, «в основе которого лежит обещание взаимопонимания и устранение барьеров для успешного общения» (Muth 2017a: 405). Следовательно, во многих европейских странах (и неевропейских также) русский язык стал занимать важное рыночное положение, что обеспечивает его роль не только как языка международного и межэтнического общения, но и как языка, имеющего экономическую ценность (см. Muth 2017b, Suryanarayan 2017, Viimaranta et al. 2017 и др.). В рамках первоначальной теории коммодификации языки определяются с точки зрения их способности приносить экономическую прибыль (Duchêne \& Heller 2012). В этом отношении изменилось положение русского языка на мировой арене языков как товаров, то есть их роли как рыночных ценностей: «Следствием этой тенденции является отход от дискурсов “гордости”, которые связывают языки с идентичностями, территориями и национальными государствами с дискурсами “прибыли”, которые представляют языки в экономических терминах как товары, полезные для производства ресурсов» (Pavlenko 2015: 387).

Вторая функция русского языка заслуживает более глубокого внимания из-за ее динамики и прямого влияния на понимание социолингвистической ценности языка. Судьба русского языка уникальна, поскольку это широко распространенный язык с множеством возможных функций: родной язык или один из первых усвоенных языков, один из родных языков или эритажный язык, язык культурного наследия, лингва-франка, язык меньшинства или язык группы меньшинства, язык коммодификации, «язык бывшего оккупанта», иностранный язык, язык как инструмент власти, инструмент мягкой силы, язык (лингвистической, политической, геополитической и пр.) напряженности, язык как формат для дебатов и т. д. Действительно, эта специфическая социолингвистическая ситуация с русским языком привела к обширной области исследований, посвященных ему как языку диаспоры и эритажному языку среди иммигрантского населения. Один из наиболее сложных вопросов связан с пониманием социальных и психолингвистических аспектов, которые определяют его сохранение в семьях иммигрантов и среди групп экспатов из разных постсоветских государств. Интересно, что сами эти страны являются важными объектами социолингвистического анализа, поскольку различные подходы к национальной языковой политике привели к весьма неоднородным статусным уровням русского языка и его присутствию в языковой среде.

В данной статье мы используем термин русскоязычные сообщества, которые многочисленны и разнообразны. Рязанова-Кларк (Ryazanova-Clarke 2014) определяет «диаспору» как менее точное обозначение всех возможных русскоязычных общин за пределами России, поскольку этот термин подразумевает сильные связи с родиной. Социолингвистические позиции русскоязычных сообществ могут быть сильнее или слабее, а с жизнеспособностью русского и его межпоколенческим сохранением или сменой во 
многом связаны статусы контактных языков и культур. Важна и роль отношения к языку, и расхождений между отношением и языковой компетенцией в иммигрантских сообществах (ср. Lasagabaster 2008).

В то же время эти новые социолингвистические реалии всегда шли и продолжают идти рука об руку с русским языком в новом обличии (Pavlenko 2017). Понимание иногда несопоставимых ситуаций может быть очень полезным для социолингвистического описания русского языка. «Важно изучить, почему на постсоветском пространстве наблюдаются различные обобщенные тенденции в использовании языка, самоидентификации и групповой идентификации» (Cheskin \& Kachuyevski 2019: 4).

Социолингвистическая ситуация с русским языком как унаследованным по-прежнему оставляет без ответа множество вопросов, и цель этого специального выпуска - способствовать более глубокому пониманию некоторых из них. В нем представлены новые сравнительные исследования по передаче и сохранению русского языка как эритажного в странах (в некоторой степени) с историческим присутствием русского языка (например, Эстония, Германия, Израиль, Швеция и США), но также и в менее изученных средах с очень недавней историей русского языка как эритажного (например, Испания, Кипр, Индия, Южная Корея и Япония). Кроме того, данный специальный выпуск призван отразить различные текущие аспекты русского языка как эритажного: в нем собраны работы о различных коммуникативных и функциональных ролях русского языка как унаследованного, о семейной языковой политике в отношении русского как эритажного в разных странах, о лонгитюдных изменениях его социолингвистического статуса и о структурных изменениях, которые носители производят в русском языке как эритажном. Таким образом, авторы обсуждают различные социолингвистические переменные, которые побуждают мигрантов первого поколения передавать или не передавать свои родные языки носителям второго поколения; особенности построения идентичности у разных поколений мигрантов; явления, которые характеризуют языковой выбор и наследие языковых систем в последующих поколениях; и заметность языков мигрантов в таких условиях, как языковой ландшафт.

\section{2. Русский язык в постсоветских иммигрантских сообществах}

В настоящее время русский язык распространен по всему миру. Помимо Российской Федерации и четырнадцати национальных государств, образовавшихся в результате распада Советского Союза, во многих странах обосновалось значительное количество русскоязычных. Кроме традиционных мест проживания в Израиле, Германии и США (Ben-Rafael et al. 2006), общины русскоязычных иммигрантов в последнее время стали особенно многочисленными в Западной Европе, на Ближнем Востоке и в Азии. Как уже указывалось выше, большинство из них связаны русским языком внутренне, а не конкретной этнической или национальной принадлежностью. Д. Лайтин 
(Laitin 1998) определил русский язык как маркер групповой идентичности среди русскоязычных сообществ за рубежом, хотя следует проявлять некоторую осторожность с точки зрения различий в идентичности и взглядах постсоветских иммигрантов. А. Ческин и А. Качуевски (Cheskin \& Kachuyevski 2019) настаивают на том, что русскоязычная идентичность сложна и варьируется в различных сообществах, в которых говорят на русском языке.

В настоящее время к русскому языку как средству общения, идентичности и коммодификации за пределами России применяются разные определения. Русский язык в постсоветских государствах принято определять как лингва-франка, язык межэтнического общения, офиџиальный язык, язык меньшинства или иностранный язык в новых социолингвистических ландшафтах. Важно отметить, что роль русского языка как лингва-франка чрезвычайно варьируется в рамках национальной политики дерусификации (Pavlenko 2006). Были проведены обширные исследования меняющихся языковых ситуаций в четырнадцати постсоветских национальных государствах (например, Pavlenko 2008). Основные результаты отличают страны Балтии с их глубокой и всепроникающей политикой в отношении национальных языков (Brubaker 2014), а также страны Кавказа, которые исключили русский язык из законодательства (Hogan-Brun \& Melnyk 2012), от стран Центральной Азии, с языковой политикой в пользу русского, которая признает русский язык либо официальным, либо языком межнационального общения (Aminov et al. 2010). Такие восточноевропейские государства, как Беларусь, Украина и Молдова, образуют особую группу стран с меняющейся динамикой языковой политики. В то время как Беларусь приняла русский язык в качестве своего второго государственного языка, который в настоящее время де-факто используется в качестве основного языка страны (Pavlenko 2013), Молдова поляризована между национальным молдавским и престижным русским (Prina 2012), а Украина проходит разные этапы языкового регулирования, включая крайнюю степень политизации языкового вопроса (Csernicskó 2017, Smaglo 2020).

В странах за пределами постсоветского пространства показателем общей характеристики для постсоветских иммигрантов является именно русский язык. В постсоветских иммигрантских сообществах русский язык часто используется в качестве лингва франка и языка межэтнического общения, независимо от этнических или национальных групп носителей (cp. Ryazantsev 2015). Важно отметить, что не все постсоветские иммигранты - русскоязычные. Для того, чтобы избежать любого поверхностного или упрощенного подхода к диаспоре, Д. Малютина (Malyutina 2020) подчеркивает важность различия между теми постсоветскими иммигрантами, которые используют русский язык, и теми, кто не хочет иметь с ним ничего общего. Это наблюдение кажется очень уместным, учитывая, что исторически сложилась общая тенденция называть «русским» любого иммигранта из бывшего Советского Союза (см., например, Andrews 1998 о такой исторической перспективе). 
Несмотря на эти различия, именно русский язык получил широкую поддержку за пределами России. Российская Федерация запустила «проект соотечественников», направленный на взаимодействие с российскими гражданами, проживающими за границей, в частности на поощрение связей с родиной и использование таких связей для продвижения России и русского языка на Западе (Byford 2012). Влияние этого проекта распространяется на многих постсоветских иммигрантов. «Русская диаспора - это не диаспора в строгом смысле слова и не “русская”» (Suslov 2017: 10): в группы соотечественников во всем мире входят не только российские граждане, проживающие за рубежом, но и иммигранты из Советского Союза, бывшие советские русскоязычные граждане, граждане России и бывшие советские граждане в целом. Эти иммигрантские общины объединены общей историей и общими воспоминаниями, и русский язык играет ключевую роль в этих связях (Elias \& Shorer-Zeltser 2006). Общий язык и культура, как ясно заявляют А. Мустайоки, Е. Протасова и М. Еленевская (Mustajoki et al. 2020a), могут гораздо сильнее способствовать успешной консолидации диаспоры, чем любой принцип идеологической или политической лояльности. Таким образом, в целом, чувство принадлежности к русскоязычной диаспоре не связано с политическими пристрастиями (Golova 2020).

В некоторых принимающих странах роль русского языка как средства общения диаспоры уже достигла значительных успехов. В Израиле, например, русский язык систематически используется в разветвленной сети печатных и электронных СМИ (Elias 2011). Еленевская и Фиалкова (Yelenevskaya \& Fialkova 2003), основываясь на нарративах иммигрантов, показали, что русскоязычные в Израиле глубоко осведомлены о ценности и функциональных возможностях русского языка. В результате русский язык используется даже в официальных ситуациях, например, в бизнесе и сфере высоких технологий. Похожая ситуация существует в Германии и США, где проживают обширные русскоязычные сообщества. В Германии около шести миллионов носителей русского языка, большинство из которых считают русский своим маркером идентичности (Hamann et al. 2020). Вследствие этого русский язык поддерживается и используется во многих контекстах: от образования (в основном, детских садов и начальных школ) до коммерческой инфраструктуры, средств массовой информации и социальных сетей, а также медицинских учреждений (Bergmann 2015). В Соединенных Штатах, где по состоянию на 2010 год более трех миллионов человек говорили по-русски (Aref'ev 2014), русский выступает в качестве языка социальной среды иммигрантов (Hubenthal 2004), который положительно воспринимается, изучается и используется многими эритажниками (Kagan 2010). Публичное присутствие русского языка в США очень широко, в том числе не только в прессе, но также в юридических и медицинских службах, образовательных учреждениях, коммерческой инфраструктуре и особенно в академических кругах 
(Kagan \& Dillon 2010). Во всех трех упомянутых странах русскоязычные группы в целом положительно относятся к русскому языку как к эритажному, обеспечивая его сохранение и передачу из поколения в поколение (cp. Moin, Schwartz \& Breitkopf 2011 про Израиль и Германию; и Kagan 2010 про США). Однако социолингвистический статус и функционирование русского языка в других странах с крупными русскоязычными сообществами не обязательно следуют такой же схеме. В некоторых из них причина может заключаться в большей рассредоточенности русскоязычных по всей стране, с разобщенными (и небольшими) связями с сообществом. Примером могут служить русскоязычные иммигранты в Великобритании, которые представляют собой довольно фрагментированное сообщество с сильными социальными и культурными различиями и разнообразными общественными практиками (Byford 2012). На рынке русскоязычных мигрантов Великобритании существует русскоязычная сеть истеблишмента, включающая материальные (продукты, рабочую силу, услуги и т.д.) и символические (информацию, услуги, контакты и т.д.) формы обмена; но она явно нацелена на рассредоточенную и несколько неопределенную целевую группу, которая в основном связана через неформальные социальные сети (Byford 2012).

В некоторых странах русскоязычные сообщества появились совсем недавно, а диаспора четко не организована. Наиболее яркими примерами могут служить русскоязычные общины в Южной Европе, где русский язык является одним из многих языков иммигрантов из числа меньшинств, со сложными, динамичными и разнообразными социолингвистическими ситуациями. В Италии, например, русскоязычное сообщество характеризуется индивидуализмом и раздробленностью, в основном из-за его относительно небольшого размера и высокой рассредоточенности по стране (Perotto 2014). В своем социолингвистическом исследовании М. Перотто (Perotto 2014) обнаружила, что большинство членов этого сообщества не очень заботится о поддержании контактов с другими русскоязычными или о сохранении русского языка.

Таким образом, социолингвистическая ситуация с русским языком в постсоветских иммигрантских сообществах очень изменчива и нестабильна. Транснациональность определяет социальную, культурную и экономическую деятельность современных диаспор (Yelenevskaya \& Protassova 2015). Это один из факторов, объясняющих социолингвистические различия в русскоязычных диаспорах, но определенно необходимы дополнительные исследования более конкретных (национальных и специфичных для сообщества) факторов, которые объясняют (и предсказывают) функциональную и символическую ценность русского языка как языка иммигрантов. В этом отношении одним из первых необходимых шагов является рассмотрение факторов, которые благоприятствуют или препятствуют сохранению русского языка как эритажного в различных сообществах по всему миру. 


\section{3. Русский язык как эритажный}

Статус русского языка как эритажного сильно различается в разных общинах. В некоторых из них русский язык - это полноценный язык, передаваемый из поколения в поколение, с долгой социолингвистической историей. Такие укоренившиеся диаспоры состоят как из потомков русскоязычных эмигрантов, так и из новых иммигрантов (Mustajoki et al. 2020a). Однако не все члены таких диаспор сохраняют русский язык и культуру с течением времени (Smyth \& Opitz 2013). Очевидно, что существует множество факторов, обусловливающих сохранение русского языка как эритажного во всем мире. Фактически даже в странах со значительными русскоязычными сообществами, таких как Германия, многие представители второго поколения иммигрантов ассимилируются лингвистически (Golova 2020). Следует добавить, что русский язык за рубежом не остается стабильным, изменения и вариации неизбежны (в качестве общего обзора см.: Ryazanova-Clarke 2014).

Социолингвистические и психолингвистические исследования эритажных языков показывают, что внешние и внутренние условия не действуют по отдельности на сохранение унаследованных языков. Существует множество факторов, влияющих на сохранение эритажного языка или его замещение с течением времени; исследования показывают роль факторов, обусловленных принимающим обществом, и факторов, исходящих от самих носителей унаследованного языка (Schalley \& Eisenchlas 2020). Действительно социальная ценность эритажного языка как языка меньшинства определяется теми ролями, которые он играет в принимающем обществе. Н. Хорнбергер (Hornberger 2005) предположил, что все глобальные характеристики принимающего сообщества играют роль в сохранении эритажного языка, включая социолингвистический статус эритажного языка, отношение к нему носителей эритажного языка и присутствие эритажного языка в различных общественных сферах (например, в образовании и на рынке труда). Функциональный потенциал унаследованного языка вне дома также важен. Частота использования и возможные коммуникативные роли эритажного языка как в семейном контексте, так и за его пределами имеют большое влияние на его жизнеспособность (Banfi 2018). Среди других факторов исследователи подчеркивают роль престижа эритажного языка и отражаемого им культурного фона (Romanowski 2021); возможности использования эритажного языка в ситуациях с социально-экономическими ресурсами, например, в сфере образования, на рынке труда, в средствах массовой информации, в системах здравоохранения или в сфере любых других государственных услуг (Aalberse et al. 2019); степень самоидентификации с культурой эритажного языка и позитивное отношение к его символическим и функциональным ценностям (Ivanova 2019); и степень воздействия на язык исторического наследия, а также сокращение такого влияния дома (Montrul 2016). Из этого следует, что следующее утверждение оказывается довольно правильным: «Возможно, главный вывод многолетних исследований в области сохранения и смены языка заключается 
в том, что существуют разнообразные факторы, которые оказывают свое влияние в конкретных случаях, и становится невозможным построить единую широко признанную теорию о сохранении и смене языка, предсказывающую, что произойдет в любой данной двуязычной среде» (Aalberse et al.: 49). Таким образом, социальные факторы систематически дополняются набором индивидуальных характеристик лиц, говорящих на языке: их возрастом, полом, семейным положением, знанием языка, причинами миграции, сроком проживания в стране пребывания, контактной группой и т.д. (Nesteruk 2010).

Относительно русского языка как эритажного можно сделать несколько замечаний. Есть несколько важных аспектов, обусловливающих сохранение русского языка как эритажного в различных русскоязычных сообществах. Среди наиболее важных факторов - контактный язык и его социальный престиж, возможности для получения образования, социально-экономические преимущества и отношение носителей к политическим и социальным коннотациям русского как национального языка России. А Мустайоки, Е. Протасова и М. Еленевская (Mustajoki et al. 2020b: 5) очень четко резюмируют это: «Неидеологическая поддержка русского языка за пределами страны - это деликатный вопрос, который не только призывает к доброй воле, но и требует экспертного знания местного языка, образовательной политики и экономической ситуации, которое может либо создать стимулы для сохранения русского языка, либо сделать его неактуальным для социально-экономической вертикальной мобильности представителей диаспор».

Во многих странах русскоязычные культурные учреждения способствуют сохранению русского языка как эритажного через воскресные школы, языковые курсы или даже (хотя и реже) регулярное школьное образование. Тем не менее, семьи играют ключевую роль в укреплении русского языка как эритажного, и в этом отношении важно понимать, как политика в отношении семейного языка создается в различных русскоязычных сообществах по всему миру.

В своем описании семейной языковой политики в русскоязычных семьях в США О. Нестерук (Nesteruk 2010) упоминает о необходимости, вслед за Дж. Фишманом, разграничивать передачу языка и сохранение языка для понимания двуязычия у эритажников: О. Нестерук указывает на то, что передача языка (использование русского языка как унаследованного детьми в семье) гораздо более распространена и успешна, чем сохранение языка (использование русского языка в качестве унаследованного последующими поколениями для выполнения различных функций). Делая акцент на русскоязычной диаспоре в США, О. Лалеко (Laleko 2013) подчеркивает, что иммигранты в третьем и четвертом поколениях, в том числе постсоветские граждане, обычно проявляют менее сильную эмоциональную озабоченность по поводу сохранения русского языка как эритажного. Ее вывод относительно судьбы русского языка как эритажного в США не очень благоприятен: «<..> предполагая, что отношение к языку дома выступает показателем 
продолжающегося межпоколенческого сохранения языка в семьях иммигрантов, мы можем выдвинуть гипотезу о том, что стремление к сохранению и активному использованию эритажного языка за пределами дома и семьи может не входить в число высших приоритетов рожденного в Америке поколения русскоязычных эритажников» (Laleko 2013: 391).

Для сравнения: социолингвистическая ситуация в Финляндии показывает, что в большинстве случаев политика в области семейного языка способствует сохранению русского языка. Е. Протасова (Protassova 2008) поясняет, что большинство русскоязычных семей выбирают школы с преподаванием на финском и русском языках или с преподаванием русского языка в качестве эритажного, хотя эти результаты показывают значительную социальную корреляцию: семьи с низким социально-экономическим статусом менее склонны подвергать своих детей влиянию русского языка как унаследованного. Аналогично М. Шварц (Schwartz 2008) показывает, что русско-еврейские иммигранты в Израиле активно участвуют в передаче своим детям русского языка как эритажного и, что немаловажно, жалуются, когда образовательные и социальные условия не обеспечивают сбалансированного владения русским языком для их детей. Таким образом, социолингвистические ситуации в отношении русского языка сильно различаются в разных странах, и исторические вопросы (например, наличие русского языка или социальная открытость к языкам мигрантов) помогут многое объяснить в дополнение к социальным и индивидуальным факторам в сохранении русского языка как эритажного. Языковые идеологии, а также управление и практика использования русского как унаследованного языка - три столпа семейной языковой политики в соответствии с классической моделью Б. Спольски (Spolsky $2004)$ - зависят от страны и образуют своего рода калейдоскоп меняющихся и неустойчивых контекстов, благоприятствующих или препятствующих сохранению русского языка как эритажного.

Кроме того, наблюдаются влияние статуса русского языка как унаследованного на его внутреннюю эволюцию и изменения и связанная с этим политика в отношении семейного языка. Ограниченное знакомство с эритажным языком может иметь важное значение для его усвоения. Например, систематически утверждается, что уменьшенное количество инпута является основной причиной трудностей с приобретением основных грамматических признаков эритажного языка, в особенности русского как унаследованного, в связи с использованием родов имен существительных (cp. Rodina et al. 2020). Что касается русского языка, соответствующие исследования были проведены во многих местах проживания иммигрантов, выявив изменения в структуре русского языка как эритажного (ср. Protassova 2008 о русском языке в Финляндии, Isurin \& Ivanova-Sullivan 2008 о русском языке в США, и Schwarz 2008 о русском языке в Израиле). Однако недавнее сравнительное исследование русского языка в Израиле, Германии, Норвегии, Латвии и 
Великобритании выявило необходимость поиска общих и противоположных черт языковых изменений в русском языке как унаследованном (Rodina et al. 2020).

\section{4. Статьи данного выпуска}

В настоящем специальном выпуске многосторонний взгляд на языки и самобытность мигрантов способствует пониманию следующих вопросов:

- Социолингвистические портреты: кто передает или не передает свой язык второму поколению? Как воспринимаются русский и другие постсоветские языки как эритажные?

- Социальная видимость языков: как эти языки включены в разные сферы использования языка (лингвистический ландшафт)?

- Знание и отношения: что постсоветские иммигранты и репатрианты думают о своих эритажных языках и как их убеждения влияют на их жизнеспособность?

- Знание, общество и языковая система: как все эти социолингвистические и когнитивные процессы влияют на трансформацию языковых систем русского и других постсоветских языков как эритажных в совокупности с их контактными языками?

Данный выпуск включает в себя тематические исследования, посвященные управлению языком в двуязычных русско-эстонских и русско-испанских семьях (Ivanova \& Zabrodskaja), социолингвистическим моделям сохранения русского языка в качестве унаследованного в Германии (Brehmer), грамматическим аспектам русского языка как эритажного в Израиле (Meir et al.), грамматическим изменениям в русском языке под влиянием английского языка среди русско-английских двуязычных иммигрантов, проживающих в США (Isurin), многоязычию и транслингвизму среди русскоязычных сообществ на Кипре, в Эстонии и в Швеции (Karpava et al.), присутствию русского языка в языковом ландшафте Нюрнберга, Германия (Ritter) и в трех азиатских странах - Индии, Японии и Южной Кореe (Protassova et al.), использованию русского, казахского и распространению английского языка в практике именования и переименования (Smagulova \& Madiyeva), а также о сохранению эритажного языка и идентичности в литовской диаспоре (Ramoniené \& Ramonaitè). В статье А. Бранец и А. Вершик (Branets \& Verschik) представлен структурный и экстралингвистический анализ рецептивного многоязычия, демонстрирующий, как эстонцы понимают украинский язык через знание русского языка. Г. Путята (Putjata) обращается к теме сохранения языка среди многоязычных учителей, суммируя результаты своего исследования, посвященного представлениям русско-ивритских говорящих о языковой нормальности в образовательной среде. Три рецензии на книги в конце данного выпуска включены с целью продемонстрировать, как в разных странах каждое новое поколение находит собственные способы использования своего эритажного языка в зависимости от отношений между языком и обществом, 
языковыми установками и восприятием. Это позволяет более отчетливо представить себе процесс сохранения русского языка и языковых контактов постсоветских иммигрантов в Европе и за ее пределами по сравнению с особыми ситуациями с участием двух или более языков, исследованных и представленных в этих научных изданиях.

\section{5. Заключение}

Из-за политической, экономической и демографической нестабильности не только этнические меньшинства (в основном евреи и этнические немцы), но и этнические группы уже независимых государств начали эмигрировать с постсоветского пространства в страны Центральной и Западной Европы. Миграция между новыми независимыми государствами, которая включала добровольное перемещение репатриантов, также стала чрезвычайно интенсивной. Как естественный результат миграционных процессов, многие языки постсоветских иммигрантов были унаследованы от семей мигрантов в новой среде и начали последовательно составлять часть их языковой среды. Лингвистический результат стал многоуровневым: в то время как некоторые постсоветские мигранты сформировали большие сообщества экспатов, которые выступают за сохранение, использование и жизнеспособность традиционных языков, многие другие интегрировались в свои принимающие общества и/или ассимилировались культурно и лингвистически, отказавшись от своего эритажного языка. Наш специальный выпуск показывает, что ни одно из этих изменений не произошло в одночасье, и сложно определить, какие социолингвистические изменения все еще продолжаются.

Ожидаемый результат специального номера - выявленные закономерности, которые определяют социолингвистические и когнитивные аспекты жизнеспособности эритажных языков, а также влияние экстралингвистических факторов на внутренние системы эритажных языков. В этом контексте в специальном номере предлагается дальнейший анализ социальных отношений в соответствующих обществах и языковых системы в эритажных языках. Эти социолингвистические реалии, окружающие русский язык, можно вкратце описать с помощью эстонской поговорки: “Heal lapsel mitu nime” («У хорошего ребенка много имен»). В своем сборнике А Мустайоки, Е. Протасова и M. Еленевская (Mustajoki et al. 2020а) задаются вопросом: «Русский язык как коммуникативный инструмент: Лингва-франка, посредник или что-то еще?» и дают обзор возможных сценариев. Данный специальный выпуск, отвечая на некоторые уже знакомые вопросы, приводит к новым вызовам; само собой разумеется, что отдельные непредвиденные особенности русского языка обнаруживаются в более сложной ситуации (например, интерференция, транслингвизм, рецептивное многоязычие).

Как показывают тематические исследования в нашем специальном номере, русский и другие языки (например, литовский) постсоветских иммигрантов в Европе и за ее пределами могут стать (культурным) 
наследием, приобретенным в основном в качестве домашнего языка, часто без осознанной осведомленности или спланированной языковой политики семьи. Многое зависит не только от определенных способов использования языка, его образовательного и экономического статуса в более широком сообществе, но и от детей как активных агентов, которые могут предоставить свои собственные наборы норм и ожиданий в отношении использования эритажного языка.

(C) Anastassia Zabrodskaja and Olga Ivanova, 2021
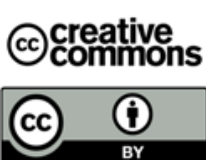

This work is licensed under a Creative Commons Attribution 4.0 International License https://creativecommons.org/licenses/by/4.0/

\section{Author contributions}

Authors 1 and 2 contributed equally and should be considered co-first authors.

\section{Acknowledgements}

This article was supported by basic funding for research areas of national significance at the Institute of Estonian and General Linguistics of the University of Tartu.

\section{REFERENCES}

Aalberse, Suzanne, Ad Backus \& Pieter Muysken. 2019. Heritage Languages. A Language Contact Approach. Amsterdam / Philadelphia: John Benjamins.

Aminov, Khalil, Vilhelm Jensen, Sherali Juraev, Indra Overland, Damir Tyan \& Yamin Uulu. 2010. Language use and language policy in Central Asia. Central Asia Regional Data Review 2 (1). 1-29.

Andrews, David R. 1998. Sociocultural Perspectives on Language Change in Diaspora. Soviet Immigrants in the Unites States. Amsterdam/Philadelphia: John Benjamins.

Aref'ev, Alexander. 2014. The Russian language in the world: Past, present, and future. Herald of the Russian Academy of Sciences 84 (5). 357-364.

Banfi, Cristina. 2018. Heritage languages in Argentina. In Corinne A. Seals \& Sheena Shah (eds.), Heritage Language Policies around the World, 48-66. London / New York: Routledge.

Ben-Rafael, Eliezer, Mikhail Lyubansky, Olaf Gluckner, Paul Harris, Yael Israel, Willy Jasper \& Julius Schoeps (eds.). 2006. Building a Diaspora. Russian Jews in Israel, Germany and the USA. Leiden/Boston: Brill.

Bergmann, Anka. 2015. Russian as a school subject in Germany: Between politics and the market. Russian Journal of Communication 7 (2). 236-241.

Brubaker, Rogers. 2014. Nationalizing states revisited: Projects and processes of nationalization in post-Soviet states. Ethnic and Racial Studies 34 (11). 1785-1814.

Byford, Andy. 2012. The Russian diaspora in international relations: 'Compatriots' in Britain. Europe-Asia Studies 64 (4). 715-735.

Cheskin, Ammon \& Angela Kachuyevski. 2019. The Russian-speaking populations in the postSoviet space: Language, politics and identity. Europe-Asia Studies 71 (1). 1-23. 
Csernicskó, István. 2017. Language policy in Ukraine: The burdens of the past and the possibilities of the future. In Simone E. Pfenninger \& Judit Navracsics (eds.), Future Research Directions for Applied Linguistics, 120-148. Briston: Multilingual Matters.

Duchêne, Alexandre \& Monica Heller (eds.). 2012. Language in Late Capitalism: Pride and Profit. London: Routledge.

Elias, Nelly \& Marina Shorer-Zeltser. 2006. Immigrant of the world unite? A virtual community of Russian-speaking immigrants on the web. The Journal of International Communication 12 (2). 70-90.

Elias, Nelly. 2011. Russian-speaking immigrants and their media: Still together? Israel Affairs 17 (1). 72-88.

Golova, Tatiana. 2020. Post-Soviet migrants in Germany, transnational public spheres and Russian soft power. Journal of Information Technology \& Politics 17 (3). 249-267.

Hamann, Katharina, Kai Witzlack-Makarevich \& Nadja Wulff. 2020. Russian in Germany. In Arto Mustajoki, Ekaterina Protassova \& Maria Yelenevskaya (eds.), The Soft Power of the Russian Language: Pluricentricity, Politics and Policies, 163-174. London/New York: Routledge.

Hogan-Brun, Gabrielle \& Svitlana Melnyk. 2012. Language policy management in the former Soviet sphere. In Bernard Spolsky (ed.), The Cambridge Handbook of Language Policy, 592-616. Cambridge: Cambridge University Press.

Hornberger, Nancy H. 2005. Heritage/community language education: US and Australian perspective. The International Journal of Bilingual Education and Bilingualism 8 (2-3). $101-108$.

Hubenthal, Wendy. 2004. Older Russian immigrants' experiences in learning English: Motivation, methods, and barriers. Adult Basic Education 14 (2). 104-126.

Isurin, Ludmila \& Tanya Ivanova-Sullivan. 2008. Lost in between: The case of Russian heritage speakers. Heritage Language Journal 6 (1). 72-104.

Ivanova, Olga. 2019. "My child is a perfect bilingual": Cognition, emotions, and affectivity in heritage language transmission. Languages 4 (2). 44.

Kagan, Olga. 2010. Russian heritage language speakers in the U.S.: A profile. Russian Language Journal 6. 214-230.

Kagan, Olga \& Kathleen Dillon. 2010. Russian in the USA. In Kim Potowski (ed.), Language Diversity in the USA, 179-194. Cambridge: Cambridge University Press.

Laitin, David. 1998. Identity in Formation. The Russian-Speaking Populations in the Near Abroad. Ithaca: Cornell University Press.

Laleko, Oksana. 2013. Assessing heritage language vitality: Russian in the United States. Heritage Language Journal 10 (3). 89-102.

Lasagabaster, David. 2008. Basque diaspora in the USA and language maintenance. Journal of Multilingual and Multicultural Development 29 (1). 66-90.

Malyutina, Daria. 2020. Whither studies of 'post-Soviet' migrants in the UK? Key themes in current academic research. In Mikhail Deniseno, Salvatore Strozza \& Matthew Light (eds.), Migration from the Newly Independent States, 533-552. Cham: Springer.

Moin, Victor, Mila Schwartz \& Anna Breitkopf. 2011. Balancing between heritage and host languages in bilingual kindergarten: Viewpoints of Russian-speaking immigrant parents in Germany and in Israel. European Early Childhood Education Research Journal 19 (4). $515-533$.

Montrul, Silvina. 2016. Losing your case? Dative experiencers in Mexican Spanish and heritage speakers in the United States. In Diego Pascual y Cabo (ed.), Advances in Spanish as a Heritage Language, 99-126. Amsterdam / Philadelphia: John Benjamins. 
Mustajoki, Arto Samuel, Ekaterina Protassova \& Maria N. Yelenevskaya (eds.). 2020a. The Soft Power of the Russian Language. Plucentricity, Politics and Policies. Abingdon: Routledge.

Mustajoki, Arto, Ekaterina Protassova \& Maria Yelenevskaya. 2020b. The Russian language away from the Metropolis: Challenges of pluricentric development. In Arto Mustajoki, Ekaterina Protassova \& Maria Yelenevskaya (eds.), The Soft Power of the Russian Language: Pluricentricity, Politics and Policies, 3-12. Abingdon: Routledge.

Muth, Sebastian. 2017a. Russian as a commodity: Medical tourism and the healthcare industry in post-Soviet Lithuania. International Journal of Bilingual Education and Bilingualism 20 (4). 404-416.

Muth, Sebastian. 2017b. Russian language abroad: Viewing language through the lens of commodification. Russian Journal of Linguistics 21 (3). 463-492.

Nesteruk, Olena. 2010. Heritage language maintenance and loss among the children of Eastern European immigrants in the USA. Journal of Multilingual and Multicultural Development 31 (3). 271-286.

Pavlenko, Aneta. 2006. Russian as a lingua franca. Annual Review of Applied Linguistics 26. 78-99.

Pavlenko, Aneta (ed.). 2008. Multilingualism in post-Soviet countries. [Special issue]. International Journal of Bilingual Education and Bilingualism 11 (3\&4).

Pavlenko, Aneta. 2013. Multilingualism in Post-Soviet Successor States. Language and Linguistics Compass 7 (4). 262-271.

Pavlenko, Aneta. 2015. Russian-friendly: How Russian became a commodity in Europe and beyond. International Journal of Bilingual Education and Bilingualism 20 (4). 385-403.

Pavlenko, Aneta. 2017. Linguistic landscape and other sociolinguistic methods in the study of the Russian language abroad. Russian Journal of Linguistics 21 (3). 493-514.

Perotto, Monica. 2014. Post-Soviet Russian-speaking diaspora in Italy: Results of a sociolinguistics survey. In Lara Ryazanova-Clarke (ed.), The Russian Language outside the Nation, 143-165. Edinburgh: Edinburgh University Press.

Pieper, Moritz. 2020. Russkiy mir: The geopolitics of Russian compatriots abroad. Geopolitics 25 (3). 756-779.

Prina, Federica. 2012. Language policies or language politics? The case of Moldova. Minority Representations and Minority Language Rights: Origins, Experiences and Lessons to be Learnt. Cluj-Napoca. http://kv.sapientia.ro/data/miremir/FEDERICA_PRINA.pdf (accessed 13 July 2021).

Protassova, Ekaterina. 2008. Teaching Russian as a heritage language in Finland. Heritage Language Journal 6 (1). 127-152.

Rodina, Yulia, Tanja Kupisch, Natalia Meir, Natalia Mitrofanova, Olga Urek \& Marit Westergaard. 2020. Internal and external factors in heritage language acquisition: Evidence from heritage Russian in Israel, Germany, Norway, Latvia and the United Kingdom. Frontiers in Education. Educational Psychology 5. 20.

Romanowski, Piotr. 2021. Family Language Policy in the Polish Diaspora: A Focus on Australia. London/New York: Routledge.

Ryazanova-Clarke, Lara (ed.). 2014. The Russian Language outside the Nation. Edinburgh: Edinburgh University Press.

Ryazanova-Clarke, Lara. 2017. From commodification to weaponization: The Russian language as 'pride' and 'profit' in Russia's transnational discourses. International Journal of Bilingual Education and Bilingualism 20 (4). 443-456.

Ryazantsev, Sergey. 2015. The modern Russian-speaking communities in the world: Formation, assimilation and adaptation in host societies. Mediterranean Journal of Social Sciences 6 (3). 155-164. 
Schalley, Andrea C. \& Susana A. Eisenchlas (eds.). 2020. Handbook of Home Language Maintenance and Development: Social and Affective Factors. Berlin/Boston: Walter de Gruyter.

Schwartz, Mila. 2008. Exploring the relationship between family language policy and heritage language knowledge among second generation Russian-Jewish immigrants in Israel. Journal of Multilingual \& Multicultural Development 29 (5). 400-418.

Smaglo, Nina. 2020. Implementation of language policy in Ukraine. The Scientific Heritage 51 (4). 43-45.

Smyth, Sarah \& Conny Opitz (ed.). 2013. Negotiating Linguistic, Cultural and Social Identities in the Post-Soviet World. Oxford, Bern, Berlin, Bruxelles, Frankfurt am Main, New York, Wien: Peter Lang Verlag.

Spolsky, Bernard. 2004. Language Policy. Cambridge: Cambridge University Press.

Suryanarayan, Neelakshi. 2017. The role of the Russian language in India's healthcare sector. Russian Journal of Linguistics 21 (3). 515-529.

Suslov, Mikhail. 2017. "Russian world": Russia's policy towards its diaspora. Notes de l'Ifri 103. https://www.ifri.org/sites/default/files/atoms/files/suslov_russian_world_2017.pdf (accessed 13 July 2021)

Ustinova, Irina. 2016. Competition with Russian as an international language. In Zoya G. Proshina \& Anna A. Eddy (eds.), Russian English. History, Functions, and Features, 225-233. Cambridge: Cambridge University Press.

Viimaranta, Hannes, Ekaterina Protassova \& Arto Mustajoki. 2017. Aspects of commodification of Russian in Finland. Russian Journal of Linguistics 21 (3). 557-586.

Yelenevskaya, Maria \& Larisa Fialkova. 2003. From 'muteness' to eloquence: Immigrant's narratives about languages. Language Awareness 12 (1). 30-48.

Yelenevskaya, Maria \& Ekaterina Protassova. 2015. Global Russian: Between decline and revitalization. Russian Journal of Communication 7 (2). 139-149.

\section{Article history:}

Received: 30 May 2021

Accepted: 15 October 2021

\section{Bionotes:}

Anastassia ZABRODSKAJA (PhD) is Professor of Intercultural Communication and Head of the Communication Management Master's programme at Tallinn University. She is in charge of the management of the European Master's in Intercultural Communication programme. Her primary research interests are identity, language contacts and linguistic landscape. She is a Regional Representative (Europe) on the Executive Committee of International Association of Language and Social Psychology and a Management Committee Member of the European Family Support Network Cost Action: A bottom-up, evidence-based and multidisciplinary approach.

\section{Contact information:}

Tallinn University

Baltic Film, Media and Arts School

Narva mnt 27, 10120 Tallinn, Estonia

e-mail: anastassia.zabrodskaja@gmail.com

ORCID: 0000-0001-8082-3549 
Olga IVANOVA is Associate Professor of General Linguistics at the Spanish Language Department of the University of Salamanca, Spain. Her primary research interest is language development during the lifespan, with particular focus on heritage language acquisition and bilingualism and language impairment in old age and dementia. Olga Ivanova is member of the research group "Neurophysiology, cognition and behaviour" of Castile-Leon Institute of Neurosciences and of the research group "Aging and dependency prevention" of Institute for Biomedical Research, both in Spain. She is founder and president of the Association for Russian as Heritage Language in Salamanca, Spain.

\section{Contact information:}

University of Salamanca

Faculty of Philology, Spanish Language Department

Plaza de Anaya s/n, 37008 Salamanca, Spain

e-mail: olga.ivanova@usal.es

ORCID: 0000-0002-9657-5380

\section{Сведения об авторах:}

Анастасия ЗАБРОДСКАЯ (PhD) - профессор межкультурной коммуникации Таллинского университета, руководитель магистерских программ «Управление коммуникацией» и «Европейские магистры по межкультурной коммуникации». Сфера ее научных интересов - идентичность, языковые контакты и языковой ландшафт. Является региональным представителем Европы в Исполнительном комитете Международной ассоциации языков и социальной психологии, а также членом Межправительственной структуры по координации национальных исследований на европейском уровне по вопросам многоязычной семьи.

\section{Контактная информация:}

Tallinn University

Baltic Film, Media and Arts School

Narva mnt 27, 10120 Tallinn, Estonia

e-mail: anastassia.zabrodskaja@gmail.com

ORCID: 0000-0001-8082-3549

Ольга ИВАНОВА - доцент кафедры испанского языка университета Саламанки, Испания. Сфера ее научных интересов включает эволюцию владения языком в течение жизни, в особенности в условиях использования эритажных языков и двуязычия, а также изменения во владении языком в пожилом возрасте. Является научным сотрудником исследовательской группы «Нейрофизиология, познание и поведение» в Институте нейронаук Кастильи и Леона, рабочей группы «Старение и профилактика зависимости» в Институте биомедицинских исследований (Испания), а также основателем и президентом Ассоциации русского языка как эритажного в Саламанке (Испания).

\section{Контактная информация:}

University of Salamanca

Faculty of Philology, Spanish Language Department

Plaza de Anaya s/n, 37008 Salamanca, Spain

e-mail: olga.ivanova@usal.es

ORCID: 0000-0002-9657-5380 